\title{
Requirements and Recommended Dietary Intakes of Protein during Infancy ${ }^{1}$
}

\author{
SAMUEL J. FOMON \\ Department of Pediatrics, College of Medicine, University of Iowa, Iowa City, Iowa 52242
}

\begin{abstract}
Two approaches have been used to arrive at estimates of the requirement for protein by infants. The factorial approach consists of adding the requirement for growth to the requirement for replacement of inevitable losses in urine and feces and from the skin. Protein requirement estimated in this way was $1.98 \mathrm{~g} \cdot \mathrm{kg}^{-1} \cdot \mathrm{d}^{-1}$ during the $1 \mathrm{st}$ mo of life and decreased rapidly to $1.18 \mathrm{~g} \cdot \mathrm{kg}^{-1} \cdot \mathrm{d}^{-1}$ by 4 to 5 mo of age, then remained at about that level to age $1 \mathrm{y}$. Believing that protein intakes of the breast-fed infant are near the level of the requirement, researchers used the intakes of breast-fed infants as a second estimate of requirement. Although intakes of protein by breast-fed infants during the first $\mathbf{2}$ mo of life are generally similar to the requirement values estimated by the factorial approach, intakes from 2 to 6 mo of age are less than the requirement values estimated by the factorial approach. Possible explanations for the discrepancy are presented. Recommended dietary intakes of protein somewhat greater than the requirements estimated by the factorial approach are proposed. These recommended intakes are less than those proposed by the FAO/WHO/UNU "safe levels of protein intake" and are less than the Recommended Dietary Allowances of the Food and Nutrition Board. (Pediatr Res 30: 391-395, 1991)
\end{abstract}

Abbreviations

RDI, recommended dietary intake

If it were possible to determine by direct experimentation the intakes of protein that would at specified ages meet the needs of 97 or $98 \%$ of normal infants, these quantities could be specified as the RDI. The mean or 50 th percentile value for requirement, the intake that would meet the needs of approximately half of the normal infant population, would then be of much less interest. However, in the absence of such evidence from direct experimentation, the most practical approach is to estimate the protein intake that meets the mean requirement, and then to increase the value to account for individual variability, with the result that the RDI would be sufficient to meet the needs of nearly all infants.

The factorial approach is commonly used to estimate the mean requirement of infants for protein. For reasons that will be presented, it seems likely that the protein intakes of breast-fed infants are near the requirement level. If this is the case, requirements for protein estimated by the factorial approach can be compared with intakes by breast-fed infants, and any major

Received April 25, 1991; accepted May 31, 1991

Correspondence: Samuel J Fomon, Department of Pediatrics, College of Medicine, University of Iowa, Iowa City, IA 52242.

'Presented on the acceptance of the Nutricia Research Foundation Award of 1991, presented at the Sophia Children's Hospital, Rotterdam, The Netherlands on April 12, 1991. discrepancy between estimated requirements and such intakes will require explanation.

\section{FACTORIAL APPROACH TO ESTIMATING REQUIREMENTS}

Calculations based on the factorial approach as applied to male infants fed milk-based formulas are summarized in Table 1 . The requirement for protein during various age intervals has been obtained by adding the quantity of protein (nitrogen $x$ 6.25 ) needed for growth to the quantity needed to replace inevitable losses in urine, in feces, and from the skin. The conversion of dietary protein (from cow milk or whey-fortified cow milk) to body protein is assumed to be $90 \%$ efficient. Because inevitable losses include nonabsorbed dietary nitrogen, no other correction for the extent of nitrogen absorption is needed.

Although replacement of losses accounts for the entire protein requirement of adult subjects and for all but a small fraction of the requirement of children beyond $2 \mathrm{y}$ of age, accretion of protein accounts for an appreciable percentage of the requirement of the young, rapidly growing infant.

Requirement for growth. The daily increment in body protein by the male reference infant (1) is presented per unit of body weight in Table 1 . Protein accretion of the female reference infant per unit of body weight averages $9 \%$ less than that of the male during the first 2 mo of life, but thereafter is quite similar. The decrease in the daily increment in body protein per unit of body weight is impressive, with a value $\left(\mathrm{g} \cdot \mathrm{kg}^{-1} \cdot \mathrm{d}^{-1}\right)$ of 0.93 in the 1st mo of life, 0.50 from 2 to 3 mo of age, 0.26 from 5 to 6 mo of age, and $0.18 \mathrm{~g} \cdot \mathrm{kg}^{-1} \cdot \mathrm{d}^{-1}$ from 9 to 12 mo of age. Between 2 and $3 \mathrm{y}$ of age, the increment in body protein is only $0.08 \mathrm{~g}$. $\mathrm{kg}^{-1} \cdot \mathrm{d}^{-1}(1)$. The protein requirement for growth (Table 1 ) is the increment in body protein divided by 0.9 (i.e. $90 \%$ efficiency of conversion of dietary protein to body protein).

Inevitable losses. When intakes of protein are in the range estimated to be at or near the level of requirement (i.e. similar to those of breast-fed infants), inevitable losses of nitrogen by the 4- to 6-mo-old infant have been estimated to be $\left(\mathrm{mg} \cdot \mathrm{kg}^{-1} \cdot \mathrm{d}^{-1}\right)$ : 91 in urine, 39 in feces, and 11 from skin, giving a total inevitable loss of $141 \mathrm{mg} \cdot \mathrm{kg}^{-1} \cdot \mathrm{d}^{-1}(2)$, equivalent to a loss of protein (nitrogen $\times 6.25$ ) of $0.88 \mathrm{~g} \cdot \mathrm{kg}^{-1} \cdot \mathrm{d}^{-1}$. Because the largest contributor to inevitable losses is tissue catabolism, inevitable losses are likely to be proportional to total body protein. The mean protein content of the male reference infant at 4 to 6 mo of age is 0.12 $\mathrm{g} / \mathrm{kg}(1)$, and total daily inevitable losses of protein at 4 to $6 \mathrm{mo}$ of age are therefore calculated to be $7.33 \mathrm{~g} / \mathrm{kg}$ of body protein. Using the body protein content of the male reference infant (1), daily inevitable losses have been presented in Table 1 for all age intervals as $7.33 \mathrm{~g} / \mathrm{kg}$ of body protein. Whether expressed per unit of body weight, per unit of fat-free body mass, or per unit of body protein, inevitable losses of nitrogen by the infant are more than twice the amount reported by Calloway and Margen (3) to be necessary to maintain balance in the adult.

Total requirement. The estimate of protein requirement for infants 3 to 4 mo of age $\left(1.27 \mathrm{~g} \cdot \mathrm{kg}^{-1} \cdot \mathrm{d}^{-1}\right)$ is $15 \%$ greater than the estimate $\left(1.1 \mathrm{~g} \cdot \mathrm{kg}^{-1} \cdot \mathrm{d}^{-1}\right)$ obtained by Beaton and Chery (4) 
by application of computer-generated simulation analysis. The estimate of protein requirement at 9 to 12 mo of age $(1.14 \mathrm{~g}$. $\left.\mathrm{kg}^{-1} \cdot \mathrm{d}^{-1}\right)$, is somewhat less than the estimate $\left(1.27 \mathrm{~g} \cdot \mathrm{kg}^{-1} \cdot \mathrm{d}^{-1}\right)$ by Huang et al. (5) for 1-y-old infants. The difference in the estimates is explained almost entirely by the use of a $90 \%$ conversion efficiency for cow milk protein to body protein in the estimates presented in Table 1 and a $70 \%$ conversion efficiency used in the calculations of Huang et al. (5).

The estimates of protein requirement for infants 1 to 2,2 to 3 , and 3 to 4 mo of age presented in Table 1 are considerably less than the corresponding estimates $(2.25,1.82$, and 1.47 $\mathrm{g} \cdot \mathrm{kg}^{-1} \cdot \mathrm{d}^{-1}$ ) by the Joint FAO/WHO/UNU Expert Consultation (6). The difference in the estimated requirements in Table 1 and those of the $\mathrm{FAO} / \mathrm{WHO} / \mathrm{UNU}$ committee are explained primarily by a $50 \%$ increase that the committee applied to the body increment in protein, and by a difference in the assumed efficiency of conversion of dietary protein to body protein-90\% of the calculations presented in Table 1 and $70 \%$ in the FAO/ WHO/UNU committee's calculations. For a diet providing a mixture of proteins, the $70 \%$ conversion factor may be appropriate, but for infants fed milk-based formulas, this conversion factor seems too low.

\section{MODEL OF BREAST-FED INFANT}

The human gene pool has been altered relatively little during the past 10000 or 12000 years. Ten thousand years ago, protein intakes were quite modest, and, in the face of marginal intakes of protein, one would anticipate that a woman who produced milk with generous quantities of protein would become protein depleted. Evolutionary forces would be expected to result in milk production that would represent the best compromise between the needs of infant and the needs of the mother $(7,8)$. If, as seems likely, the protein intake of the breast-fed infant is near the level of requirement, the protein intake of the breast-fed infant can be used as a separate estimate of requirement.

Milk intake per day. Based on data from three sources (9-11), Table 2 presents an estimate of the quantity of milk consumed by male breast-fed infants during 1-mo intervals from birth to 6 mo of age. The data of Neville et al. (10) have been included for each interval and, after adjustment for sex specificity, have been averaged with the data of Whitehead and Paul (9) for the age intervals 1 to 2,2 to 3 , and 3 to 4 mo and averaged with the data of Stuff and Nichols (11) for the age intervals 4 to 5 and 5 to $6 \mathrm{mo}$.

For the age intervals 1 to 2,2 to 3 , and 3 to $4 \mathrm{mo}$, the data of Neville et al. (10) were adjusted to reflect an intake of milk by males 17,11 , and $7 \%$, respectively, greater than that by females.

Table 1. Protein requirement estimated by factorial approach (Male infants fed milk-based formulas)

\begin{tabular}{|c|c|c|c|c|c|}
\hline \multirow{2}{*}{$\begin{array}{c}\text { Age } \\
\text { interval } \\
\text { (mo) }\end{array}$} & \multicolumn{4}{|c|}{ Protein $\left(\mathrm{g} \cdot \mathrm{kg}^{-1} \cdot \mathrm{d}^{-1}\right)$} & \multirow{2}{*}{$\begin{array}{l}\text { Growth } \\
\text { requirement } \\
(\%) \S\end{array}$} \\
\hline & Increment* & Growth† & Lossesł & Requirement & \\
\hline $0-1$ & 0.93 & 1.03 & 0.95 & 1.98 & 52 \\
\hline $1-2$ & 0.70 & 0.78 & 0.93 & 1.71 & 46 \\
\hline $2-3$ & 0.50 & 0.56 & 0.90 & 1.46 & 38 \\
\hline $3-4$ & 0.34 & 0.38 & 0.89 & 1.27 & 30 \\
\hline $4-5$ & 0.27 & 0.30 & 0.88 & 1.18 & 25 \\
\hline $5-6$ & 0.26 & 0.29 & 0.89 & 1.18 & 24 \\
\hline $6-9$ & 0.23 & 0.26 & 0.91 & 1.17 & 22 \\
\hline $9-12$ & 0.18 & 0.20 & 0.94 & 1.14 & 18 \\
\hline
\end{tabular}

* From Fomon et al. (1).

$\dagger$ Assuming $90 \%$ efficiency in converting dietary protein to body protein.

$\$$ Inevitable losses of nitrogen (in urine and feces and from skin) $\times$ 6.25 , assuming $1.17 \mathrm{~g}$ nitrogen loss per $\mathrm{kg}$ of body protein. Body protein content from Fomon et al. (1).

$\S \%$ of total requirement.
Table 2. Estimated protein intake of male breast-fed infants

\begin{tabular}{|c|c|c|c|c|}
\hline \multirow{2}{*}{$\begin{array}{c}\text { Age } \\
\text { interval } \\
(\mathrm{mo})\end{array}$} & \multicolumn{2}{|c|}{ Milk consumption } & \multirow{2}{*}{$\begin{array}{c}\text { "Protein" } \\
\text { concentration } \\
(\mathrm{g} / \mathrm{L}) \ddagger\end{array}$} & \multirow{2}{*}{$\begin{array}{l}\text { "Protein" } \\
\text { intake } \\
\left(\mathrm{g} \cdot \mathrm{kg}^{-1} \cdot \mathrm{d}^{-1}\right)\end{array}$} \\
\hline & $(\mathrm{mL} / \mathrm{d})^{*}$ & $\left(\mathrm{~mL} \cdot \mathrm{kg}^{-1} \cdot \mathrm{d}^{-1}\right) \dagger$ & & \\
\hline $0-1$ & 630 & 149 & 14.0 & 2.09 \\
\hline $1-2$ & 773 & 157 & 10.1 & 1.59 \\
\hline $2-3$ & 787 & 136 & 8.7 & 1.18 \\
\hline $3-4$ & 810 & 125 & 8.6 & 1.06 \\
\hline $4-5$ & 827 & 120 & 8.3 & 1.00 \\
\hline $5-6$ & 852 & 114 & 8.3 & 0.95 \\
\hline
\end{tabular}

* Data of Neville et al. (10) adjusted for sex specificity (see text), and averaged with data of Whitehead and Paul (9) for ages 1-2, 2-3, and 3$4 \mathrm{mo}$, and with data of Stuff and Nichols (11) for ages 4-5 and 5-6 mo.

$\dagger$ Birth weight was assumed to be $3.4 \mathrm{~kg}$ and gains in weight were as described by Guo et al. (12) with adjustment to reflect $9.4 \%$ lesser gain by male breast-fed than by male formula-fed infants (13). Body weight used in the calculation was the mean of the weight at the beginning and end of the interval.

$\ddagger$ Based on the data of Lemons et al. (14) for 0-1 mo, on the data of Nagasawa et al. (15) and Lönnerdal et al. (16) for 1-2, 2-3, and 3-4 mo, and the data of Lönnerdal et al. (16) and Stuff and Nichols (11) for 4-5 and 5-6 mo. "Protein" concentration is bioavailable nitrogen $\times 6.25$ (see text).

These differences correspond to those reported by Whitehead and Paul (9). For example, the quantity of milk consumed (by males and females) was calculated from the data of Neville $e t$ al. (10) to be $580 \mathrm{~g} / \mathrm{d}$; this value was multiplied by 1.085 to reflect the $17 \%$ greater intake by males than by females. For the age intervals 4 to 5 and 5 to $6 \mathrm{mo}$, the data of Neville et al. were adjusted to reflect an intake by males $11 \%$ greater than that by females, as reported by Stuff and Nichols (11). For the interval birth to $1 \mathrm{mo}$, the intake by males was assumed to be $10 \%$ greater than that by females.

As may be seen in Table 2, milk consumption increased gradually from $630 \mathrm{~g} / \mathrm{d}$ during the $1 \mathrm{st}$ mo of life to $852 \mathrm{~g} / \mathrm{d}$ from 5 to 6 mo of age. The data of Hofvander et al. (17) for male breast-fed infants within 1 wk of ages 1,2 , and 3 mo were 663 , 791 , and $811 \mathrm{~g} / \mathrm{d}$, respectively - intakes quite similar to those reported in Table 2 . However, considerably greater intakes have been reported by Nommsen et al. (18). If the intake of $811 \mathrm{~g} / \mathrm{d}$ reported by these authors for 3-mo-old infants is adjusted for sex specificity, as was done with the data of Neville et al. (10), the intake of $856 \mathrm{~mL} / \mathrm{d}$ for males is considerably greater than the intakes presented in Table 2 for infants 2 to 3 and 3 to 4 mo of age.

Milk intake per unit of body weight. To permit expression of intakes in relation to body weight, an estimate of body weight at the beginning and end of each age interval was made and the average of the two values was used. The mean birth weight was assumed to be $3.4 \mathrm{~kg}$, and the monthly gains were taken from the data of Guo et al. (12), with a correction for the $8 \%$ lesser rate of gain of male breast-fed than of male formula-fed infants (13).

Based on the average body weight values for each age interval, intakes of milk were greatest from 1 to $2 \mathrm{mo}$ of age $\left(157 \mathrm{~g} \cdot \mathrm{kg}^{-1}\right.$. $\mathrm{d}^{-1}$ ) and decreased to $114 \mathrm{~g} \cdot \mathrm{kg}^{-1} \cdot \mathrm{d}^{-1}$ by 5 to 6 mo of age (Table 2). Intakes reported by Wallgren (19) are somewhat greater than those presented in Table 2, especially for ages 2 to 3 and 3 to 4 mo (147 and $135 \mathrm{~g} \cdot \mathrm{kg}^{-1} \cdot \mathrm{d}^{-1}$, respectively), whereas intakes reported by Butte and Garza (20) for infants $1,2,3$, and 4 mo of age, if adjusted for sex specificity, are in close agreement with those presented in Table 2 .

Available nitrogen in human milk. Nonprotein nitrogen accounts for a major fraction of the nitrogen of human milk, averaging in mature milk about $24 \%$ of total nitrogen $(15,16)$. Most of this nonprotein nitrogen consists of urea, creatinine, uric acid, and ammonia, which appear to be largely unavailable for protein synthesis $(21-24)$. However, the amino acids, peptides, 
glucosamines, and a small percentage of the non- $\alpha$-amino nitrogen is bioavailable, accounting for about $27 \%$ of the total nonprotein nitrogen of human milk.

The concentration of bioavailable nitrogen in human milk at various ages as presented in Table 2 has been calculated from several reports in the literature that presented data on concentrations of total and nonprotein nitrogen (14-16) or on concentration of protein nitrogen only (11). When only protein nitrogen was presented, nonprotein nitrogen was estimated on the assumption that the partition between protein and nonprotein nitrogen was $76: 24$. The concentration of bioavailable nitrogen was calculated as the sum of protein nitrogen and $27 \%$ of nonprotein nitrogen, and this sum was multiplied by 6.25 to give the concentration of bioavailable nitrogen as the equivalent of protein (listed as "protein" concentration in Table 2 ).

For the 1 st mo of lactation, calculations of the concentration of bioavailable nitrogen were based on the average concentration of nitrogen in milk of mothers of term infants studied by Lemons et al. (14) at 7, 14, 21, and $28 \mathrm{~d}$ of lactation. Similar calculations for 1 to 2,2 to 3 , and 3 to 4 mo of lactation were based on the data of Nagasawa et al. (15) and Lönnerdal et al. (16), and for 4 to 5 and 5 to 6 mo of age on the data of Lönnerdal et al. (16) and Stuff and Nichols (11).

The estimates of "protein" concentration obtained from these data are $14.0 \mathrm{~g} / \mathrm{L}$ for the $1 \mathrm{st}$ mo of lactation, $10.1 \mathrm{~g} / \mathrm{L}$ for the 2nd mo of lactation, and only $8.3 \mathrm{~g} / \mathrm{L}$ between 4 and 6 mo of lactation (Table 2). Calculations based on the data of Butte and Garza (20) yield values for the concentration of bioavailable nitrogen times the factor 6.25 that are somewhat greater than those listed in Table 2 . The protein concentrations reported by Nommsen et al. (18), 12.1, 11.4, 11.6, and $12.4 \mathrm{~g} / \mathrm{L}$ at 3, 6, 9, and 12 mo of lactation, are so much greater than other values reported in the literature that one suspects a laboratory error.

Protein intake of male breast-fed infant. With the exception of the 1 st mo of life, the intakes of "protein" (bioavailable nitrogen $\times 6.25$ ) of the male breast-fed infant as presented in Table 2 are less than those presented previously (2). The greater estimates presented in the earlier publication were the consequence of an overestimate of the protein concentration of human milk between 1 and 3 mo of lactation and an overestimation of quantity of milk consumed between 3 and 6 mo of age. The intakes of protein by male breast-fed infants as estimated by the Joint FAO/WHO/UNU Expert Consultation (6), 2.46, 1.93, 1.74, and $1.49 \mathrm{~g} \cdot \mathrm{kg}^{-1} \cdot \mathrm{d}^{-1}$ during the age intervals birth to 1,1 to 2,2 to 3 , and 3 to $4 \mathrm{mo}$, are remarkably high. The high FAO/WHO/ UNU estimate for the 1st mo of life seems to have arisen because intakes for 2 to 4 wk of life were applied to the entire 1 st mo. The high FAO/WHO/UNU estimates for later age intervals are explained primarily by the assumption that the concentration of protein in human milk is $11.5 \mathrm{~g} / \mathrm{L}$.

\section{COMPARISON OF ESTIMATED PROTEIN REQUIREMENTS AND ESTIMATED PROTEIN INTAKES BY BREAST-FED} INFANTS

Protein intakes by breast-fed infants during the first 2 mo of life (Table 2) do not differ greatly from the estimated requirements (Table 1). However, for infants from 2 to 5 mo of age, the estimated requirements for protein are 18 to $24 \%$ greater than the estimated intakes of the breast-fed infant. This observation warrants discussion. Four reasons for the difference need to be considered: 1) the estimates of protein requirements of infants fed milk-based formulas are too high; 2) requirements calculated for infants fed milk-based formulas are inappropriate for judging the adequacy of protein intake by breast-fed infants; 3 ) the estimated protein intakes of breast-fed infants are too low; and 4) the intakes of protein by breast-fed infants fail to meet the requirement.

Possibility that estimates of protein requirement for infants fed milk-based formulas are too high. Errors in the estimated protein requirements for the formula-fed infant might arise from overestimating the protein increment, from underestimating the efficiency of conversion of dietary protein to body protein, or from overestimating inevitable losses. None of these possibilities can be dismissed, but the least likely would appear to be that the conversion efficiency (assumed to be 90\%) has been underestimated.

Possibility that requirements calculated for infants fed milkbased formulas are inappropriate for judging adequacy of protein intake by breast-fed infants. Calculations based on data from formula-fed infants might be inappropriate for breast-fed infants because the increment in body protein and, therefore, the protein requirement for growth, are less for breast-fed infants and/or because the efficiency of conversion of dietary protein to body protein is greater for human milk protein than for cow milk protein.

Rates of gain in weight and length are less by breast-fed than by formula-fed infants (13), and it seems likely that the increment in protein, based on data from studies of formula-fed infants (1) is somewhat excessive for breast-fed infants. Gains in length of male formula-fed infants during the early months of life are $8 \%$ more rapid than gains in length of breast-fed infants (13). If one were to decrease the estimated requirements for protein for growth by $8 \%$ in each age interval in Table 1 , the resulting protein requirement value would be $1.90 \mathrm{~g} \cdot \mathrm{kg}^{-1} \cdot \mathrm{d}^{-1}$ during the 1 st mo of life $(9 \%$ less than the estimated intake by the breastfed infant) and $1.65 \mathrm{~g} \cdot \mathrm{kg}^{-1} \cdot \mathrm{d}^{-1}$ during the 2 nd mo of life ( $4 \%$ less than the estimated intake by the breast-fed infant). However, from 2 to 5 mo of age, when protein for growth is a smaller percentage of the protein requirement, the estimate of protein requirement, even with this correction, would average $21 \%$ greater than the estimated protein intake of male breast-fed infants. The estimates of protein requirements from 2 to $5 \mathrm{mo}$ of age would be decreased only slightly if one were to assume an efficiency of conversion of human milk protein to body of $95 \%$ rather than the $90 \%$ conversion efficiency assumed for cow milk

Thus, it does not seem likely that calculations of requirements based on data from formula-fed infants rather than from breastfed infants are the major explanation that estimated protein intakes by breast-fed infants are less than the estimated protein requirements.

Possibility that estimated intakes of protein by breast-fed infants are too low. Data on quantities of milk consumed by breastfed infants have been determined by a number of investigators using the test weighing method. Most investigators have reported intakes similar to those presented in Table 2. However, some investigators, notably Nommsen et al. (18), have reported greater intakes. Moreover, validation studies carried out by isotope dilution methods $(25,26)$ have not been completely convincing. Thus, it is possible that milk consumption estimated by test weighing results in some underestimation of intake.

The percentage of nonprotein nitrogen that is bioavailable appears to be low for the breast-fed $(22,24)$ as well as for the formula-fed infant (23). Although a few reports indicate that protein concentrations in human milk are greater than those listed in Table 2, the values listed in Table 2 are considered to be the best available. Underestimation of protein intake by the breast-fed infant seems less likely to result from underestimation of the protein concentration of human milk than from underestimation of milk intake.

In explaining the discrepancy between the calculated protein intake of the breast-fed infant and the protein requirement calculated for the formula-fed infant, underestimation of the protein intake of the breast-fed infant is probably less important than overestimation of the requirement of the formula-fed infant.

Possibility that protein intake by breast-fed infants may be less than optimal. Some readers will find it offensive even to suggest that breast feeding may not provide an optimal intake of protein after the 2 nd mo of life. However, by a slight decrease in growth rate, the infant might compensate for a slightly suboptimal intake 
of protein while deriving the benefit of all of the other advantages of breast feeding.

Recognizing that fat-free body mass is an abstraction and that each cell requires lipid for structure and function, it is, nevertheless, useful in considerations of growth to distinguish between growth of fat and growth of fat-free body mass. Growth of fatfree body mass, together with its essential lipid components, is regulated quite differently from growth of adipose tissue. A reasonable hypothesis is that each infant has a genetically determined potential for growth of fat-free body mass. If he remains free from major illness and receives adequate intakes of energy and essential nutrients, he will meet his growth potential. According to this hypothesis, the ideal growth rate is that which provides the maximum gain in fat-free tissue without an excessive gain in fat.

Thus, the slightly less rapid growth of fat-free body mass of the breast-fed than of the formula-fed infant, as indicated by the difference in gain in length, suggests that breast feeding, despite its overriding advantages from other points of view, is less than ideal in permitting the infant to achieve his growth potential. It is possible that protein is a limiting nutrient. Nevertheless, if breast feeding fails to provide an optimal intake of protein, the intake must at least quite closely approach the optimal intake. Indices of protein nutritional status other than growth of fat-free body mass are similar for breast-fed infants and for formula-fed infants, who receive much more generous intakes of protein. It is certainly difficult to imagine that the protein intake of the breast-fed infant from 2 to 5 mo of age could be $17 \%$ less than the requirement.

Conclusion about reasons for difference between estimated requirement for protein after 2 mo of age and protein intake of breast-fed infants. Of the possibilities considered, none can be confidently excluded as a contributor to the difference between the estimated requirement for protein and the calculated protein intakes by the breast-fed infant. However, the most important reason for the difference is almost surely overestimation of the protein requirement.

\section{PROTEIN REQUIREMENT}

The mean energy and protein requirements during various age intervals are summarized in Table 3. Mean protein requirements, i.e. intakes estimated to meet the requirements of half of the infants of the stated age, are presented as $\mathrm{g} \cdot \mathrm{kg}^{-1} \cdot \mathrm{d}^{-1}$ (as in Table 1) and, based on the average requirement for energy, as $g / 100$ kcal.

Whether expressed as $\mathrm{g} \cdot \mathrm{kg}^{-1} \cdot \mathrm{d}^{-1}$ or as $\mathrm{g} / 100 \mathrm{kcal}$, it is evident that the average protein requirement decreases rapidly during the first 4 mo of life, and then declines only slightly during the next 8 mo. With increasing age, mean protein requirement per unit of body weight decreases 14 to $16 \%$ monthly through 4 mo of age. The decrease from the interval 3 to 4 mo to the interval 4 to $5 \mathrm{mo}$ is only $7 \%$, and subsequent decreases are quite minor. Decreases in mean protein requirement per unit of energy intake

Table 3. Summary of estimated requirements for energy and

\begin{tabular}{cccc} 
& \multicolumn{3}{c}{ protein } \\
\cline { 2 - 4 } $\begin{array}{c}\text { Age interval } \\
(\mathrm{mo})\end{array}$ & $\begin{array}{c}\text { Menergy }(\mathrm{kcal} \cdot \\
\left.\mathrm{kg}^{-1} \cdot \mathrm{d}^{-1}\right)\end{array}$ & \multicolumn{2}{c}{ Protein } \\
\cline { 2 - 4 } & 120 & 1.98 & 1.65 \\
$0-1$ & $\left.1 \mathrm{~g} \cdot \mathrm{kg}^{-1} \cdot \mathrm{d}^{-1}\right)$ & $(\mathrm{g} / 100 \mathrm{kcal})$ \\
$1-2$ & 110 & 1.71 & 1.55 \\
$2-3$ & 100 & 1.46 & 1.46 \\
$3-4$ & 95 & 1.27 & 1.34 \\
$4-5$ & 90 & 1.18 & 1.31 \\
$5-6$ & 90 & 1.18 & 1.31 \\
$6-9$ & 90 & 1.17 & 1.30 \\
$9-12$ & 90 & 1.14 & 1.26 \\
\hline
\end{tabular}

$(\mathrm{g} / 100 \mathrm{kcal})$ are 6 to $8 \%$ per month through the first 4 mo of life. The decrease from the interval 3 to 4 mo to the interval 4 to $5 \mathrm{mo}$ is only $2 \%$. Thus, protein requirements of infants from 3 to 4 mo of age are more similar to those of older infants than to those of infants less than 3 mo of age.

\section{RDI OF PROTEIN}

Several considerations were taken into account in using the estimated requirements for protein as a basis for developing RDI. Because the efficiency of conversion of cow milk protein to body protein is likely to be greater than that for certain other proteins used in infant formulas (e.g. isolated soy protein) and for many protein components of beikost, the protein requirements were recalculated using a $70 \%$ rather than a $90 \%$ factor for efficiency of conversion of dietary protein to body protein. An increase above this new calculation of requirement was then introduced to account for individual variability.

Of the two components of the protein requirement-protein for growth and protein to replace inevitable losses of nitrogenmost of the variability in the requirement would seem to be in the growth component. Inevitable losses of nitrogen are related, at least in part, to body size; therefore, when expressed per unit of body weight, variability of this component of the protein requirement is likely to be rather low.

The variability in body protein increment (equivalent to the variability in protein requirement for growth) is probably better reflected by variability in length gain than by variability in weight gain. During the early months of life, much of the variability in weight gain is the result of variability in fat deposition. As indicated by the data of Guo et al. (12) for the 2-mo intervals birth to 2,1 to 3,2 to 4,3 to 5 , and 4 to 6 mo of age, 2 SD for gain in length average about $26 \%$ of the mean; after 6 mo of age, the variability in gain in length is less than before 6 mo of age.

RDI for first 2 mo of life. Assuming that the variability in protein requirement for growth is similar to the variability in gain in length, the mean protein requirement for growth, calculated with a $70 \%$ efficiency of conversion of dietary protein to body protein, has been increased by $26 \%$. This value added to the value for inevitable losses is presented in Table 4 as the RDI. As may be seen from Table 4, the RDI for protein for birth to 1 mo of age is $2.6 \mathrm{~g} \cdot \mathrm{kg}^{-1} \cdot \mathrm{d}^{-1}$, and the RDI for 1 to 2 mo of age is $2.2 \mathrm{~g} \cdot \mathrm{kg}^{-1} \cdot \mathrm{d}^{-1}$. Based on the energy intakes in Table 3 , the RDI are also presented as $\mathrm{g} / 100 \mathrm{kcal}$.

RDI for infants beyond 2 mo of age. Based on the observation that the estimate of requirement for infants 2 to 5 mo of age was 18 to $24 \%$ greater than the estimated protein intakes of breastfed infants, the requirement estimate presented in Table 1 for infants over 2 mo of age was believed to be high. After recalculating the protein requirement figures for growth with a conversion efficiency of $70 \%$ rather than $90 \%$, the RDI were set $10 \%$ above the estimates of protein requirement.

The RDI for protein presented in Table 4 are considerably less than the FAO/WHO/UNU "safe levels of protein intake" (6). For infants 3 to 6,6 to 9 , and 9 to 12 mo of age, the FAO/

Table 4. RDI of protein

\begin{tabular}{ccc}
\hline $\begin{array}{c}\text { Age interval } \\
(\mathrm{mo})\end{array}$ & \multicolumn{2}{c}{$\mathrm{RDI}^{*}$} \\
\cline { 2 - 3 }$\left(\mathrm{g} \cdot \mathrm{kg}^{-1} \cdot \mathrm{d}^{-1}\right)$ & $(\mathrm{g} / 100 \mathrm{kcal})$ \\
\hline $0-1$ & 2.6 & 2.2 \\
$1-2$ & 2.2 & 2.0 \\
$2-3$ & 1.8 & 1.8 \\
$3-4$ & 1.5 & 1.6 \\
$4-5$ & 1.4 & 1.6 \\
$5-6$ & 1.4 & 1.6 \\
$6-9$ & 1.4 & 1.5 \\
$9-12$ & 1.3 & 1.5 \\
\hline
\end{tabular}

* See text for method of determining RDI from estimated requirement values. 
WHO/UNU recommendations are $1.86,1.65$, and $1.48 \mathrm{~g} \cdot \mathrm{kg}^{-1}$. $\mathrm{d}^{-1}$, respectively. The Recommended Dietary Allowances (27) are patterned after the $\mathrm{FAO} / \mathrm{WHO} / \mathrm{UNU}$ recommendations but have been presented for only two age intervals: $2.2 \mathrm{~g} \cdot \mathrm{kg}^{-1} \cdot \mathrm{d}^{-1}$ for birth to $6 \mathrm{mo}$ and $1.6 \mathrm{~g} \cdot \mathrm{kg}^{-1} \cdot \mathrm{d}^{-1}$ for 6 to $12 \mathrm{mo}$.

\section{RECOMMENDED MINIMUM PROTEIN CONCENTRATION OF INFANT FORMULAS}

The United States Food and Drug Administration specifies the lower limit of protein in infant formulas to be $1.8 \mathrm{~g} / 100 \mathrm{kcal}$. This value would seem to merit revision. For the first 2 mo of life, the lower limit is less than the RDI presented in Table 4 and less than has been demonstrated to be adequate. A minimum level of protein of $2.2 \mathrm{~g} / 100 \mathrm{kcal}$ is recommended for infants less than 3 mo of age. For infants over 3 mo of age, a protein concentration of $1.6 \mathrm{~g} / 100 \mathrm{kcal}$ is considered adequate.

\section{REFERENCES}

1. Fomon SJ, Haschke F, Ziegler EE, Nelson SE 1982 Body composition of reference children from birth to age ten years. Am J Clin Nutr 35:11691175

2. Fomon SJ 1986 Protein requirements of term infants. In: Fomon SJ, Heird WC (eds) Energy and Protein Needs during Infancy. Academic Press, New York, pp 55-68

3. Calloway $\mathrm{DH}$, Margen S 1971 Variation in endogenous nitrogen excretion and dietary nitrogen utilization as determinants of human protein requirements. J Nutr 101:205-216

4. Beaton $\mathrm{GH}$, Chery A 1988 Protein requirements of infants: a reexamination of concepts and approaches. Am J Clin Nutr 48:1403-1412

5. Huang PC, Lin CP, Hsu JY 1980 Protein requirements of normal infants at the age of about 1 year: maintenance nitrogen requirements and obligatory nitrogen losses. J Nutr 110:1727-1735

6. Joint FAO/WHO/UNU Expert Consultation 1985 Energy and Protein Requirements. World Health Organization, Technical Report Series 724, Geneva, Switzerland

7. Dugdale AE 1986 Evolution and infant feeding. Lancet 1:670-673

8. Peaker M 1989 Evolutionary strategies in lactation: nutritional implications. Proc Nutr Soc 48:53-57

9. Whitehead RG, Paul AA 198 I Infant growth and human milk requirements. A fresh approach. Lancet 2:161-163

10. Neville MC, Keller R, Seacat J, Lutes V, Neifert M, Casey C, Allen J, Archer P 1988 Studies in human lactation: milk volumes in lactating women during the onset of lactation and full lactation. Am J Clin Nutr 48:1375-1386
11. Stuff JE, Nichols BL 1989 Nutrient intake and growth performance of older infants fed human milk. J Pediatr 115:959-968

12. Guo S, Roche AF, Fomon SJ, Nelson SE, Chumlea C, Rogers RR, Baumgartner RN, Ziegler EE, Siervogel RM 1991 Reference data for gains in weight and length during the first two years of life. J Pediatr (in press)

13. Nelson SE, Rogers RR, Ziegler EE, Fomon SJ 1989 Gain in weight and length during early infancy. Early Hum Dev 19:223-239

14. Lemons JA, Moye L, Hall D, Simmons M 1982 Differences in the composition of preterm and term human milk during early lactation. Pediatr Res 16:113117

15. Nagasawa T, Kiyosawa I, Fukuwatari Y, Kitayama T, Uechi M, Hyodo Y $1973 \alpha$-Lactalbumin and serum albumin in human milk. J Dairy Sci 56:177180

16. Lönnerdal B, Forsum E, Hambraeus L 1976 A longitudinal study of the protein, nitrogen, and lactose contents of human milk from Swedish wellnourished mothers. Am J Clin Nutr 29:1127-1133

17. Hofvander Y, Hagman U, Hillervik C, Sjölin S 1982 The amount of milk consumed by $1-3$ month old breast- or bottle-fed infants. Acta Paediatr Scand 71:953-958

18. Nommsen LA, Lovelady CA, Heinig MJ, Lönnerdal B, Dewey KG 1991 Determinants of energy, protein, lipid, and lactose concentrations in human milk during the first 12 mo of lactation: the DARLING study. Am J Clin Nutr 53:457-465

19. Wallgren A 1944-45 Breast-milk consumption of healthy full-term infants. Acta Paediatr 32:778-790

20. Butte NF, Garza C 1985 Energy and protein intakes of exclusively breastfed infants during the first four months of life. In: Gracey M. Falkner F (eds) Nutritional Needs and Assessment of Normal Growth. Nestle Nutrition, Vevey/Raven Press, New York, pp 63-83

21. Heine W, Tiess M, Stolpe HJ, Wutzke K 1984 Urea utilization by the intestinal flora of infants fed mother's milk and a formula diet, as measured with ${ }^{15} \mathrm{~N}$ tracer technique. J Pediatr Gastroenterol Nutr 3:709-712

22. Heine $\mathrm{W}$, Tiess M, Wutzke KD $1986{ }^{15} \mathrm{~N}$ tracer investigations of the physiological availability of urea nitrogen in mother's milk. Acta Paediatr Scand 75:439-443

23. Fomon SJ, Matthews DE, Bier DM, Rogers RR, Rebouche CJ, Edwards BB Nelson SE 1987 Bioavailability of dietary urea nitrogen for the infant. J Pediatr 111:221-224

24. Fomon SJ, Bier DM, Matthews DE, Rogers RR, Edwards BB, Ziegler EE, Nelson SE 1988 Bioavailability of dietary urea nitrogen in the breast-fed infant. J Pediatr 113:515-517

25. Butte NF, Wong WW, Patterson BW, Garza C, Klein PD 1988 Human-milk intake measured by administration of deuterium oxide to the mother: comparison with the test-weighing technique. Am J Clin Nutr 47:815-821

26. Butte NF, Wong WW, Klein PD, Garza C 1991 Measurement of milk intake: tracer-to-infant deuterium dilution method. $\mathrm{Br} J$ Nutr $65: 3-14$

27. Food and Nutrition Board, Subcommittee on the Tenth Edition of the RDAs 1989 Recommended Dietary Allowances, 10th Ed. National Academy Press, Washington, DC 